\title{
Erratum to: Transanal endoscopic surgery using a single access port: a practical tool in the surgeon's toybox
}

I. E. Gorgun - Erman Aytac • Meagan M. Costedio •

Hasan H. Erem • Michael A. Valente •

Luca Stocchi

Published online: 8 January 2014

(C) Springer Science+Business Media New York 2014

Erratum to: Surg Endosc

DOI 10.1007/s00464-013-3267-y

The last name (family name) of the first author is Gorgun.

The correct spelling is I. E. Gorgun.

The online version of the original article can be found under doi:10.1007/s00464-013-3267-y.

I. E. Gorgun $(\varangle) \cdot$ E. Aytac · M. M. Costedio ·

H. H. Erem - M. A. Valente - L. Stocchi

Department of Colorectal Surgery, Digestive Disease Institute,

Cleveland Clinic, 9500 Euclid Ave, Cleveland, OH 44195, USA

e-mail: gorgune@ccf.org

E. Aytac

e-mail: eaytactr@yahoo.com 